\title{
Common mental disorders and associated factors: a study of women from a rural area*
}

\section{Transtorno mental comum e fatores associados: estudo com mulheres de uma área rural Trastornos mentales comunes y factores asociados: estudio de las mujeres en una zona rural}

Bibiane Dias Miranda Parreira ${ }^{1}$, Bethania Ferreira Goulart ${ }^{1}$, Vanderlei José Haas ${ }^{2}$, Sueli Riul da Silva ${ }^{2}$, Juliana Cristina dos Santos Monteiro3 ${ }^{3}$, Flávia Azevedo Gomes-Sponholz ${ }^{3}$

How to cite this article:

Parreira BDM, Goulart BF, Haas VJ, Silva SR, Monteiro JCS, Gomes-Sponholz FA. Common mental disorders and associated factors: a study of women from a rural area. Rev Esc Enferm USP. 2017;51:e03225. DOI: http://dx.doi.org/10.1590/S1980-220X2016033103225

* Extracted from the thesis "Saúde mental e reprodutiva de mulheres em área rural de Uberaba - Minas Gerais", Escola de Enfermagem de

Ribeirão Preto, Universidade de São Paulo, 2016.

1 Universidade Federal do Triângulo Mineiro, Instituto de Ciências da Saúde, Departamento de Enfermagem, Uberaba, MG, Brazil.

2 Universidade Federal do Triângulo Mineiro, Programa de Pós-Graduação em

Atenção à Saúde, Uberaba, MG, Brazil.

3 Universidade de São Paulo, Escola

de Enfermagem de Ribeirão Preto,

Ribeirão Preto, SP, Brazil.

\section{ABSTRACT}

Objective: Identifying the prevalence of Common Mental Disorders and analyzing the influence of sociodemographic, economic, behavioral and reproductive health variables on Common Mental Disorders in women of childbearing age living in the rural area of Uberaba-MG, Brazil. Method: An observational and cross-sectional study. Sociodemographic, economic, behavioral and reproductive health instruments were used, along with the Self-Reporting Questionnaire (SRQ-20) to identify common mental disorders. Multiple logistic regression was used for multivariate data analysis. Results: 280 women participated in the study. The prevalence of Common Mental Disorders was $35.7 \%$. In the logistic regression analysis, the variables of living with a partner and education level were associated with Common Mental Disorders, even after adjusting for the other variables. Conclusion: Our findings evidenced an association of social and behavioral factors with Common Mental Disorders among rural women. Identification and individualized care in primary health care are essential for the quality of life of these women.

\section{DESCRIPTORS}

Women; Rural Population; Mental Health; Psychiatric Nursing; Primary Care Nursing. 


\section{INTRODUCTION}

Common Mental Disorders (CMD) are characterized by depression symptoms, states of anxiety, irritability, fatigue, insomnia, difficulty in memory and concentration, and somatic complaints ${ }^{(1)}$. They manifest as a mixture of somatic, anxious and depression symptoms ${ }^{(2)}$.

Early and correct diagnosis of these disorders is fundamental to avoid physical and psychological damage to the individual and burden to the health system. In this sense, it should be highlighted that actions of the Family Health Strategy (ESF - Estratégia de Saúde da Família) can help in detecting, referring and treating $C M D$, considering its accessibility and coverage characteristics ${ }^{(3)}$. Therefore, articulating mental health with the Family Health Strategy (FHS) is relevant ${ }^{(4)}$.

Gender differences are present in CMD, predominantly affecting women ${ }^{(2,5-8)}$. Some Brazilian studies have shown the prevalence of CMD in women in urban areas to be: $33.8 \%{ }^{(8)}$, $37.9 \%^{(6)}, 41.7 \%^{(3)}, 52.1 \%{ }^{(7)}$.

Considering the few national studies with women in the rural context, the prevalence of CMD in women is high for this population group $-56.2 \%{ }^{(9)}, 44.17 \%^{(5)}$ and $43.6 \%{ }^{(10)}$.

Literature points out that in rural and urban contexts, several social, cultural and behavioral factors may be related to CMD. Results obtained in several national studies involving urban and rural contexts have revealed a higher prevalence of CMD related to: women ${ }^{(5-8)}$, low education levels ${ }^{(9)}$, low income ${ }^{(7)}$ and to separated, divorced, widowed or single women ${ }^{(6,9)}$.

In relation to the rural context, living conditions associated with poverty, stressful events, limited social and economic resources, and other demographic disadvantages pose a greater risk for mental health problems ${ }^{(11)}$.

For rural women, mental health issues may be more pronounced, although some aspects such as living in a more calm and secluded community may be conducive to mental health, other aspects can be stressful. These women may have fewer opportunities for paid employment, fewer social contacts, less access to health services compared to urban women $^{(12)}$, as well as a lack of perspective for improving living conditions and the physical overload of work.

The lack of job opportunities in the rural area is a reality. Low supply associated with transportation difficulty compromises the possibility of the option to make income. According to data presented in a Bangladesh study, $86.0 \%$ of rural women were housewives ${ }^{(13)}$. However, in a different study conducted in Bangladesh, nearly half of the rural participants were engaged in income-generating activities ${ }^{(14)}$.

In a study developed in Rio Grande do Sul, Brazil 96.7\% of the participants performed agricultural and domestic work $^{(15)}$, thus demonstrating physical overload and the vulnerability of these women. It is believed that there are variations in socio-cultural roles and their association with gender and the inhabited region, being rural or urban ${ }^{(16)}$.

Moreover, people living in rural communities have limited access to health services and specialized services such as mental health services. Women living in rural areas with low education levels are less likely to seek care for mental illness compared to women living in urban areas ${ }^{(17)}$.

From this perspective, we emphasize that several factors can influence the mental health of rural women. The interaction between environmental, social, cultural, economic and individual issues highlights the uniqueness of this population.

Specific groups such as women are a priority focus in public policies, especially for issues related to reproductive health. However, there is still a gap in issues related to mental health, specifically in the attention to rural women.

It is believed that social, economic, behavioral and reproductive health factors influence the mental health of rural women, and thus can have a number of consequences on their quality of life.

The mental health of rural women of reproductive age is essential both for their quality of life and for the wellbeing of their children and their families. Faced with this reality, national studies that identify CMDs in women living in rural areas and their association with different factors are needed.

A review of the literature has demonstrated that national studies in this area are scarce. Further studies can provide subsidies for actions of the health team working in rural areas and nursing practice in the prevention, identification, referral and follow-up of women who present symptoms of mental illness.

In view of the above, the objectives of this study were: to identify the prevalence of CMD and to analyze the influence of sociodemographic, economic, behavioral and reproductive health variables on CMD in women of childbearing age living in the rural area of the city of Uberaba, state of Minas Gerais.

\section{METHOD}

An observational study with a cross-sectional design carried out in the rural area of the city of Uberaba, state of Minas Gerais, Brazil.

The rural area of the municipality of Uberaba is covered by the FHS. There are four FHS teams.

After contacting all the FHS teams of the rural municipality, the Santa Rosa FHS was selected to be the data collection site. This team was selected due to a greater number of women in the age group between 15 to 49 years, according to the list provided by the rural Basic Health Unit managers (UBS - Unidade Básica de Saúde). Another factor that contributed to selecting this team was the complete number of active community health agents (CHA), providing visiting coverage throughout the area.

Women aged between 15 and 49 in the rural area of the Santa Rosa FHS from the municipality of Uberaba-MG, participated in the study.

Inclusion criteria were: women living in the rural area of the Santa Rosa FHS in the municipality of Uberaba-MG, for more than one year; aged between 15 and 49 years; and women possessing faculties in terms of time, space and person.

A pilot test was performed in order to observe the applicability and suitability of the data collection instru- 
ments, revealing the need for small adjustments which were duly performed.

During data collection, the home visits were carried out in the company of the coverage area's CHA. A list with the women's names to be included in the study had been previously comprised. Subsequently, the schedule of CHA visits was followed as defined monthly by the FHS nurse. The provided list was followed as a reference during the visits.

Data collection was carried out between October 2014 and May 2015 at the homes of participating women in the form of direct interviews, even though the instruments were self-applicable. This choice was made considering that some women might have difficulty reading or understanding the questions, or even tiredness, which could interfere in their answers and the results of the study. The interviews were conducted face to face by a single researcher at the home, in a reserved place to ensure confidentiality and privacy.

There were 345 women on the list provided by the FHS team. Of these, 122 were excluded as 77 had moved out of the rural area under study, 33 were not found at home after three attempts by the interviewer, one had passed away, four were excluded due to age, five refused to participate in the study and two had cognitive decline. Five women participated in the pilot study. At the time of data collection, 62 women who were not on the list were included because they met the inclusion criteria. Thus, a total of 280 women participated in the study.

Sociodemographic, economic, behavioral and reproductive health instruments were elaborated based on the literature, scientific research carried out in the area and previous experience of the researchers. The instruments were submitted to content validation and to appreciation by three judging experts in the area. The investigated variables were: age, education level, skin color, marital status, occupation, individual income, amount of individual income, family income, physical activity, leisure activity, smoking habit, chronic illness, relationship with a partner, pregnancy, children and occurrence of abortions.

The Self-Reporting Questionnaire (SRQ-20) was used to assess the prevalence of CMD. This is an instrument designed for screening rather than for diagnosis. It is recommended by WHO for community studies and basic health care in populations of developing countries ${ }^{(18)}$. It consists of 20 questions with yes/no answers. Each positive response corresponds to 1 point; at the end, a summation of the points represents the final score. The result can range from zero (no probability of CMD) to 20 (extreme probability of CMD). On the performance evaluation of SRQ-20 as a psychiatric screening instrument, the most appropriate cut-off point for SRQ-20 was 7/8, regardless of gender, with $86.33 \%$ sensitivity and $89.31 \%$ specificity. A total score equal or below seven classifies as a negative case, while a score equal or greater than eight is considered positive for the 20 questions $^{(18)}$. This was the cut-off point used to classify CMD in this study.

Data were entered into a spreadsheet in the Excel ${ }^{\circledR}$ program using the double-entry validation technique to detect inconsistencies. Statistical analysis was performed with SPSS software (Statistical Package for Social Sciences) for Windows version 20.0.

In the univariate analysis, data were presented as the distribution of absolute ( $\mathrm{n}$ ) and relative (\%) frequencies for qualitative variables; and as mean values, standard deviations, and maximum and minimum values for quantitative variables. In the bivariate analysis, existence of association was verified through contingency tables and their respective association measures: Pearson's Chi-square test $\left(\mathrm{X}^{2}\right)$, Prevalence Ratio (PR) and prevalence odds ratio (POR). Multiple logistic regression was used for the multivariate analysis.

Inclusion of the predictor variables considered national and international literature relevant for the outcome of CMD. The predictive variables used for the multiple logistic regression were: education level (quantitatively classified), individual income (classified in two categories: "yes", "no"), leisure activity (classified in two categories: "yes”, "no"), relationship with a partner (classified in two categories: "good", "bad"), and number of children living (quantitatively classified).

Internal consistency of the SRQ-20 instrument responses was measured by the Kuder-Richardson Coefficient (kr-20).

A confidence interval (CI) of $95.0 \%$ and a significance level $\alpha$ of $5 \%$ were considered for all tests.

The present investigation began after receiving approval from the Municipal Secretary of Health of the Uberaba Municipality and project approval by the Research Ethics Committee of the Ribeirão Preto School of Nursing of the Universidade de São Paulo (USP), under protocol no. 280/2013 and CAAE 21860113.2.0000.5393.

The women were invited to participate in the study and clarified about the nature and objectives of the research. Those who agreed to participate formalized their agreement by signing the informed consent form. In the case of adolescents or minors, acceptance was requested to the adolescents and their legal representatives who formalized their acquiescence by also signing the consent form.

\section{RESULTS}

The study included women aged between 15 to 49 years, mean age of 33.6 years and standard deviation (SD) of 9.8 . Regarding their education level, the mean was 7.0 years of schooling ( $\mathrm{SD}=3.3$ ). Schooling time ranged from 0 to 15 years. The majority were considered white $(72.1 \%)$, married or in a stable union (83.6\%), with no paid occupation, housewives $(55.7 \%)$, without individual monthly income (45.4\%), and among those who had individual income, most earned off-the-books income (21.8\%), and the value of individual income was one minimum wage (51.0\%). The predominant family income value was between one and two minimum wages $(37.2 \%)$.

Regarding behavioral characterization, the majority of women did not perform physical activity (80.7\%), engaged in leisure activities (54.3\%), reported that they did not have any chronic diseases (73.9\%), did not smoke (78.2\%) and answered "good" regarding the relationship with their partner $(91.9 \%)$. 
Considering the reproductive health of the participants, $91.0 \%$ of the women had already been pregnant, and $17.2 \%$ reported having an abortion/miscarriage, and they were not questioned whether it was spontaneous or induced. The mean number of pregnancies was $2.8(\mathrm{SD}=1.7)$ gestations. Mean occurrence of abortions was $1.5(\mathrm{SD}=0.8)$. The mean number of living children was $2.5(\mathrm{SD}=1.43)$ children per woman.

CMD prevalence was $35.7 \%$ according to the study participants' responses to the SRQ-20 scale.
Internal consistency on the SRQ-20 was 0.87 , as measured by the $\mathrm{kr}-20$ coefficient.

In the bivariate analysis, the variables: not engaging in leisure activity $(p=0.04)$, having chronic disease $(p<0.001)$ and reporting a "bad" relationship with the partner $(p<0.001)$ were associated with CMD (Table 1).

Table 1 presents the bivariate analysis of sociodemographic, economic, behavioral and reproductive health variables related to CMD among women living in the rural area.

Table 1 - Distribution of women living in rural areas according to sociodemographic, economic, behavioral and reproductive health variables and CMD - Uberaba, Minas Gerais, Brazil, 2014-2015

\begin{tabular}{|c|c|c|c|c|c|c|c|}
\hline \multirow{3}{*}{ VARIABLES } & \multicolumn{4}{|c|}{ AFFECTED BY CMD } & \multirow{3}{*}{$\begin{array}{c}\text { PR } \\
(95 \% \mathrm{Cl})\end{array}$} & \multirow{3}{*}{$\begin{array}{c}\text { POR } \\
(95 \% \mathrm{CI})\end{array}$} & \multirow{3}{*}{$\mathbf{p}^{*}$} \\
\hline & \multicolumn{2}{|c|}{ YES } & \multicolumn{2}{|c|}{ NO } & & & \\
\hline & $\mathbf{n}$ & $\%$ & $\mathbf{n}$ & $\%$ & & & \\
\hline Living with a partner & & & & & & & 0.25 \\
\hline Yes & 87 & 37.2 & 147 & 62.8 & 1.32 & 1.50 & \\
\hline No & 13 & 28.3 & 33 & 71.7 & $(0.81-2.15)$ & $(0.75-3.01)$ & \\
\hline Paid occupation & & & & & & & 0.80 \\
\hline Yes & 39 & 34.8 & 73 & 65.2 & 0.96 & 0.94 & \\
\hline No & 61 & 36.3 & 107 & 63.7 & $(0.69-1.33)$ & $(0.57-1.55)$ & \\
\hline Individual income & & & & & & & 0.56 \\
\hline Yes & 57 & 37.3 & 96 & 62.7 & 1.10 & 1.16 & \\
\hline No & 43 & 33.9 & 84 & 66.1 & $(0.80-1.51)$ & $(0.71-1.90)$ & \\
\hline Physical activity & & & & & & & 0.30 \\
\hline Yes & 16 & 29.6 & 38 & 70.4 & 0.80 & 0.71 & \\
\hline No & 84 & 37.2 & 142 & 62.8 & $(0.51-1.24)$ & $(0.37-1.35)$ & \\
\hline Leisure activity & & & & & & & 0.04 \\
\hline Yes & 46 & 30.3 & 106 & 69.7 & 0.72 & 0.60 & \\
\hline No & 54 & 42.2 & 74 & 57.8 & $(0.52-0.98)$ & $(0.36-0.97)$ & \\
\hline Smoking habit & & & & & & & 0.06 \\
\hline Yes & 28 & 45.9 & 33 & 54.1 & 1.40 & 1.73 & \\
\hline No & 72 & 32.9 & 147 & 67.1 & $(1.00-1.95)$ & $(0.97-3.09)$ & \\
\hline Chronic disease & & & & & & & $<0.001$ \\
\hline Yes & 41 & 56.2 & 32 & 43.8 & 1.97 & 3.21 & \\
\hline No & 59 & 28.5 & 148 & 71.5 & $(1.47-2.65)$ & $(1.85-5.58)$ & \\
\hline Relationship with their partner & & & & & & & $<0.001$ \\
\hline Good & 72 & 33.5 & 143 & 66.5 & 0.42 & 0.13 & \\
\hline Bad & 15 & 78.9 & 4 & 21.1 & $(0.32-0.57)$ & $(0.04-0.42)$ & \\
\hline Children & & & & & & & 0.16 \\
\hline Yes & 89 & 37.4 & 149 & 62.6 & 1.43 & 1.68 & \\
\hline No & 11 & 26.2 & 31 & 73.8 & $(0.84-2.44)$ & $(0.81-3.52)$ & \\
\hline Abortion & & & & & & & 0.45 \\
\hline Yes & 18 & 42.9 & 24 & 57.1 & 1.17 & 1.30 & \\
\hline No & 74 & 36.6 & 128 & 63.4 & $(0.79-1.73)$ & $(0.66-2.55)$ & \\
\hline
\end{tabular}

${ }^{*} p$-value for the Chi-square test.

Table 2 presents the results of multiple logistic regression analysis regarding the association of $\mathrm{CMD}$ with the variables of education level, individual income, leisure activity, relationship with their partner and number of living children. 
Table 2 - Association between sociodemographic, economic, behavioral and reproductive health variables and CMD in rural women in a multiple logistic regression model - Uberaba, Minas Gerais, Brazil, 2014-2015

\begin{tabular}{|c|c|c|c|c|c|c|c|}
\hline \multirow{3}{*}{ VARIABLES } & \multicolumn{4}{|c|}{ AFFECTED BY CMD } & \multirow{3}{*}{$\begin{array}{c}\text { POR } \\
(95 \% \mathrm{CI})\end{array}$} & \multirow{3}{*}{$\begin{array}{c}\text { Adjusted POR } \\
(95 \% \mathrm{CI})\end{array}$} & \multirow{3}{*}{$\mathbf{p}^{*}$} \\
\hline & \multicolumn{2}{|c|}{ YES } & \multicolumn{2}{|c|}{ NO } & & & \\
\hline & $\mathbf{n}$ & $\%$ & $\mathbf{n}$ & $\%$ & & & \\
\hline \multirow[t]{2}{*}{ Education level** } & - & - & - & - & - & 0.88 & 0.02 \\
\hline & & & & & & $(0.80-0.98)$ & \\
\hline \multicolumn{8}{|l|}{ Individual income } \\
\hline Yes & 57 & 37.3 & 96 & 62.7 & 1.16 & 1.19 & 0.57 \\
\hline No & 43 & 33.9 & 84 & 66.1 & $(0.71-1.90)$ & $(0.66-2.16)$ & \\
\hline \multicolumn{8}{|l|}{ Leisure activity } \\
\hline Yes & 46 & 30.3 & 106 & 69.7 & 0.60 & 0.82 & 0.51 \\
\hline No & 54 & 42.2 & 74 & 57.8 & $(0.36-0.97)$ & $(0.45-1.49)$ & \\
\hline \multicolumn{8}{|l|}{ Relationship with the partner } \\
\hline Good & 72 & 33.5 & 143 & 66.5 & 0.13 & 0.16 & 0.002 \\
\hline Bad & 15 & 78.9 & 4 & 21.1 & $(0.04-0.42)$ & $(0.05-0.51)$ & \\
\hline \multirow[t]{2}{*}{ Number of alive children** } & - & - & - & - & - & 1.11 & 0.33 \\
\hline & & & & & & $(0.90-1.38)$ & \\
\hline
\end{tabular}

* $p$ value for the maximum likelihood test.

** Quantitative variable.

The variables of education level (adjusted $\mathrm{POR}=0.88$, 95.0\% CI (0.80-0.98) $p=0.02)$ and relationship with their partner (adjusted POR $=0.16,95.0 \%$ CI $(0.05-0.51)$, $p=0.002$ ) were associated to $\mathrm{CMD}$, even after adjustment for the other previously recognized variables in national and international literature. Therefore, a "good" relationship with their partner reduces the woman's chances of having CMD by $84 \%$, and each additional year of education decreases the woman's chances of having CMD by $12 \%$, even after adjusting for the individual income variables, leisure activity and number of children.

It should be noted that among women with CMD, the mean the education level was 6.0 years of study $(\mathrm{SD}=3.2)$, and among those without CMD, the mean was 7.5 years of studying $(\mathrm{SD}=3.2)$.

The mean number of living children among women with CMD was 2.9 children (SD=1.6), and among those who did not present $\mathrm{CMD}$, the mean was 2.3 children $(\mathrm{SD}=1.3)$.

\section{DISCUSSION}

The prevalence of CMD in the present study was 35.7\%. A study conducted among rural women residing in Rio Grande do Norte found a prevalence of $43.6 \%{ }^{(10)}$. Another national study carried out with mothers from the semi-arid region of Alagoas found CMD prevalence of $56.2 \%$ in the rural area, being higher when compared to the urban prevalence which was $43.8 \% \%^{(9)}$. Moreover, a study in the area of Zona da Mata in Pernambuco identified prevalence of CMD among the participating population (men and women) of $36.0 \%$, and among women it was $44.17 \%{ }^{(5)}$. In relation to the present study, a lower prevalence of CMD was evidenced in relation to the national studies in rural areas.

However, in two international studies conducted in the rural area of Pakistan, high prevalence of CMD was identified among women of $66 \%$ and $57.5 \%$, respectively ${ }^{(19-20)}$. A different result was shown in a study in rural villages in India, where $22.8 \%$ of the 658 women participants were affected by CMD when the SRQ-20 was used ${ }^{(21)}$.

In a study carried out in Ethiopia with 512 people living in rural and urban areas, rural residents (33.3\%) had a higher prevalence of CMD compared to those in the urban area, and in women (33\%) when compared to men ${ }^{(22)}$.

In studies performed in the urban environment, the authors found a higher prevalence of CMD among women when compared to our study. We emphasize that although the urban environment has different characteristics from the rural environment, women in the cited studies may be similar to the women investigated in our study due to the issue of domestic work and work overload.

Other national studies in the urban environment with a general population (of men and women) identified the prevalence of CMD among women attended by the UBS in the city of Ribeirão Preto $(44.1 \%)^{(23)}$, in a city in the interior of São Paulo $(52.1 \%)^{(7)}$, in the city of Barbacena $(41.7 \%)^{(3)}$ and in a medium-sized municipality in the Center-West region of Brazil $(37.9 \%)^{(6)}$.

In a cohort study with 15,105 people from six Brazilian cities, the authors identified that the prevalence of CMD was more frequent among women (33.8\%), showing a lower rate than in the present study ${ }^{(8)}$.

We found that the prevalence of CMD identified in the present study shows lower results than those presented in most national and international studies conducted in rural and urban areas. However, this prevalence is worrisome considering the impact that CMD can have on the lives of rural women and their families.

In multiple logistic regression, the variables of relationship with their partner and education level were associated to $\mathrm{CMD}$, even after adjusting for the other variables. A "good" relationship with a partner decreases the woman's 
chances of having CMD by $84 \%$, as well as each year of schooling by $12 \%$.

A study developed in the rural area of Alagoas found no significant association of CMD with the variables of education level, age and number of children after logistic regression analysis; the variable that maintained association in this study was not having a partner ${ }^{(9)}$.

In relation to education level, the results agree with studies carried out in urban areas and with the study carried out with rural women in Pakistan, where after multiple regression analysis, the variables of education level, not having a partner/companion and having four or more children were associated with the SRQ score (the lower the education level, the higher the SRQ score $)^{(24)}$. We emphasize that in this cited study, the score rather than the prevalence was verified, as similar to our study.

In a study conducted in the semi-arid urban region of Alagoas, education level was associated with $\mathrm{CMD}^{(9)}$. Data evidenced in Feira de Santana after multiple logistic regression analysis confirmed the association between domestic overload and CMD, adjusted for income, education level and leisure activities ${ }^{(25)}$.

However, after multiple logistic regression analysis in the present study, the variables of individual income, leisure activity and number of children did not present a significant association with CMD. Not having a "good" relationship with the partner was an important factor for the presence of the CMD, as well as low education level.

In a study of 3,504 pregnant women in rural Bangladesh, $35 \%$ had a positive score on SRQ-20. The study showed that all forms of domestic violence were associated with higher levels of $\mathrm{CMD}^{(26)}$.

The present study did not investigate the issue of domestic violence, however a "bad" relationship with their partner was a fact that should be considered and treated with attention. The gender issue associated with the socioeconomic disadvantages of rural women may be associated with CMD, as evidenced in the present study.

Therefore, the presence of CMD is closely linked to social disadvantage factors ${ }^{(7)}$. Low education level is associated with socioeconomic conditions. The main social consequence of this situation is the lack of opportunity, as well as the difficulty to improve the educational and social situation of these people ${ }^{(25)}$.
Management practices in primary care, in addition to the need for advancement in the educational and social levels of people are important to improve the mental health of the community ${ }^{(22)}$.

\section{CONCLUSION}

The results showed that the prevalence of CMD among the rural women participating in the study was lower than those presented in other studies in the rural context.

The results also identified that the relationship with their partner and the education level were related to CMD. Therefore, having a "bad" relationship with their partner is a factor that can have repercussions on rural women's mental health, as evidenced in the study. Education level also prevailed over other variables identified in the literature. On the other hand, a "good" relationship with their partner and higher education level are factors that reduce CMD risks among rural women.

Early identification and individualized care in primary health care through trained health professionals and health services prepared for identification and appropriate intervention are essential to reduce mental health complications. The use of validated instruments such as the one used in this study represents potential tools that can contribute to CMD recognition and identification. Among these health professionals, we highlight nurses for developing health care and educational practices. Actions developed by these professionals through nursing consultations, home visits, group activities, among others, provide approximation and bonding of women, helping to identify the symptoms related to CMD. Using validated instruments such as the SRQ-20 should be encouraged in professional practice in order to contribute to health care.

We hope that the results of this study can contribute to the analysis and reflection of this theme, as well as to creating/designing efficient action plans for providing mental health care to rural women.

The limitations of this study were: it was a cross-sectional study, so it was not able to infer causality; the number of losses, mainly due to the change of address; and the study being conducted in a single rural area, which could limit information regarding women from other rural areas.

\section{RESUMO}

Objetivo: Identificar a prevalência do transtorno mental comum e analisar a influência de variáveis sociodemográficas, econômicas, comportamentais e de saúde reprodutiva sobre o transtorno mental comum em mulheres em idade fértil, residentes na zona rural do município de Uberaba-MG, Brasil. Método: Estudo observacional e transversal. Foram utilizados instrumentos de caracterização sociodemográfica, econômica, comportamental e de saúde reprodutiva, e o Self-Reporting Questionnaire (SRQ-20) para identificar os transtornos mentais comuns. $\mathrm{Na}$ análise multivariada dos dados, foi utilizada a regressão logística múltipla. Resultados: Participaram do estudo 280 mulheres. A prevalência do transtorno mental comum foi de $35,7 \%$. $\mathrm{Na}$ análise de regressão logística, as variáveis convivência com o companheiro e escolaridade, associaram-se ao transtorno mental comum, mesmo após o ajuste para as demais variáveis. Conclusão: Os achados evidenciaram a associação de fatores sociais e comportamentais com o transtorno mental comum, entre mulheres rurais. A identificação e a assistência individualizada na atenção primária de saúde são essenciais para a qualidade de vida destas mulheres.

Mulheres; População Rural; Saúde Mental; Enfermagem Psiquiátrica; Enfermagem de Atenção Primária. 


\section{RESUMEN}

Objetivo: Identificar la prevalencia de trastornos mentales comunes y analizar la influencia de las variables socio-demográficas, económicas, de comportamiento y de salud reproductiva en el trastorno mental común en las mujeres en edad fértil, que viven en el municipio rural de Uberaba, Minas Gerais, Brasil. Método: Estudio observacional y transversal. Se usaron instrumentos sociodemográficos, económicos, de comportamiento y salud reproductiva, y el Self-Reporting Questionnaire (SRQ-20) para identificar los trastornos mentales comunes. En el análisis multifactorial de los datos, se utilizó la regresión logística múltiple. Resultados: El estudio incluyó a 280 mujeres. La prevalencia de los trastornos mentales comunes fue de 35,7\%. En el análisis de regresión logística, las variables convivencia con su pareja y la escolarización se asociaron con trastorno mental común, incluso después de ajustar por otras variables. Conclusión: Los resultados muestran la relación entre los factores sociales y de comportamiento con el trastorno mental común entre las mujeres rurales. La identificación y la atención individual en la atención primaria de salud son esenciales para la calidad de vida de las mujeres.

\section{DESCRIPTORES}

Mujeres; Población Rural; Salud Mental; Enfermería Psiquiátrica; Enfermería de Atención Primaria.

\section{REFERENCES}

1. Goldberg D, Huxley P. Common mental disorders: a bio-social model. London: Routledge; 1992.

2. Malhotra S, Shah R. Women and mental health in India: an overview. Indian J Psychiatry. 2015;57(6):205-11.

3. Vidal CEL, Yañez BFP, Chaves CVS, Yañez CFP, Michalaros IA, Almeida LAS. Transtornos mentais comuns e uso de psicofármacos em mulheres. Cad Saúde Coletiva. 2013;21(4):457-64.

4. Paiva PC, Torrenté MON, Landim FLP, Branco JGO, Tamboril BCR, Cabral ALT. Psychological distress and community approach to the voice of the community health agent. Rev Esc Enferm USP. 2016;50(n.spe):134-9. DOI: http://dx.doi.org/10.1590/S0080-623420160000300020

5. Costa AG, Ludemir AB. Transtornos mentais comuns e apoio social: estudo em comunidade rural da Zona da Mata de Pernambuco, Brasil Cad Saúde Pública. 2005; 21(1):73-9.

6. Lucchese R, Sousa K, Bonfin SP, Vera I, Santana FR. Prevalência de transtorno mental comum na atenção primária. Acta Paul Enferm. 2014;27(3):200-7.

7. Gomes VF, Miguel TLB, Miasso AI. Common mental disorders: socio-demographic and pharmacotherapy profile. Rev Latino Am Enfermagem. 2013;21(6):1203-11.

8. Nunes MA, Pinheiro AP, Bessel M, Brunoni AR, Kemp AH, Bensen IM, et al. Common mental disorders and sociodemographic characteristics: baseline findings of the Brazilian Longitudinal Study of Adult Health (ELSA-Brasil). Rev Bras Psiquiatr. 2016;38(2):91-7.

9. Paffer AT, Ferreira HS, Cabral Júnior CR, Miranda CT. Prevalence of common mental disorders in mothers in the semiarid region of Alagoas and its relationship with nutritional status. São Paulo Med J. 2012;130(2):84-91.

10. Costa MGSG, Dimenstein MDB, Leite JF. Condições de vida, gênero e saúde mental entre trabalhadoras rurais assentadas. Estud Psicol. $2014 ; 19(2): 145-54$.

11. Simmons LA, Wu Q, Yang N, Bush HM, Crofford LJ. Sources of health information among rural women in Western Kentucky. Public Health Nurs. 2015;32(1):3-14.

12. Hillemeier MM, Weisman CS, Chase GA, Dyer AM. Mental health status among rural women of reproductive age: findings from the Central Pennsylvania Women's Health Study. Am J Public Health. 2008;98(7):1271-79.

13. Rahman M, Rahman A, Sajani TT, Chowdhury SA, Akhter A. Reproductive health practice of married women in the rural community of Dhamrai Upazila, Dhaka. Anwer Khan Modern Med Coll J. 2013; 4(2):31-6.

14. Shariful Islam SM, Mainuddin A. Relationship between income generating activities of rural women and their reproductive health behavior in Bangladesh. Rural Remote Health. 2015;15(4):3216.

15. Cezar-Vaz MR, Clarice Alves Bonow CA, Santos da Silva MR. Mental and physical symptoms of female rural workers: relation between household and rural work. Int J Environ Res Public Health. 2015;12(9):11037-49.

16. Habtamu K, Atalay Alem A, Medhin G, Fekadu A, Prince M, Hanlon C. Development and validation of a contextual measure of functioning for people living with severe mental disorders in rural Africa. BMC Psychiatry. 2016;16(1):311.

17. Dolja-Gore X, Loxton DJ, D'Este CA, Byles JE. Mental health service use: is there a difference between rural and non-rural women in service uptake? Aust J Rural Health. 2014;22(3):92-100.

18. Gonçalves DM, Stein AT, Kapczinski F. Avaliação de desempenho do Self-Reporting Questionnaire como instrumento de rastreamento psiquiátrico: um estudo comparativo com o Structured Clinical Interview for DSM-IV-TR. Cad Saúde Pública. 2008; 24(2):380-90.

19. Husain N, Creed F, Tomenson B. Depression and social stress in Pakistan. Psychol Med. 2000;30(2):395-402.

20. Mumford DB, Saeed K, Ahmad I, Latif S, Mubbashar MH. Stress and psychiatric disorder in rural Punjab. A community survey. Br J Psychiatry.1997;170:473-8.

21. Soni A, Fahey N, Byatt N, Prabhakaran A, Moore Simas TA, Vankar J, et al. Association of common mental disorder symptoms with health and healthcare factors among women in rural western India: results of a cross-sectional survey. BMJ Open. 2016; 6(7):e010834.

22. Yimam K, Kebede Y, Azale T. Prevalence of common mental disorders and associated factors among adults in Kombolcha Town, Northeast Ethiopia. J Depress Anxiety. 2014;S1:007. DOI: 10.4172/2167-1044.S1-007

23. Borges TL, Hegadoren KM, Miasso AI. Transtornos mentais comuns e uso de psicofármacos em mulheres atendidas em unidades básicas de saúde em um centro urbano brasileiro. Rev Panam Salud Publica. 2015;38(3):195-201. 
24. Husain N, Gater R, Tomenson B, Creed F. Social factors associated with chronic depression among a population-based sample of women in rural Pakistan. Soc Psychiatry Psychiatr Epidemiol. 2004;39(8):618-24.

25. Pinho OS, Araújo TM. Associação entre sobrecarga doméstica e transtornos mentais comuns em mulheres. Rev Bras Epidemiol. 2012;15(3):560-72.

26. Ziaei S, Frith AL, Ekstrom EC, Naved RT. Experiencing lifetime domestic violence: associations with mental health and stress among pregnant women in rural Bangladesh: the MINIMat Randomized Trial. PLoS One. 2016;11(12):e0168103. 